\title{
PENGEMBANGAN VIDEO PEMBELAJARAN BERBASIS TPACK DALAM MATERI PECAHAN UNTUK SISWA KELAS IV SD
}

\author{
Rebica Afsari, Nila Kesumawati, Nora Surmilasari \\ Surel: Rebicaafsari73@gmail.com
}

\begin{abstract}
This study aims to develop TPACK-based learning videos in fraction material for fourth grade elementary school students that are valid, practical and have a potential effect on student learning outcomes. This research is research and development using the ADDIE model with five stages, namely analysis, design, development, implementation, and evaluation. The research took place at SDN 79 Prabumulih. The research subjects were 20 fourth grade elementary school students. Data collection was carried out by means of a media expert validation questionnaire, material expert, student response questionnaire, and student test questions. The data are analyzed quantitatively and qualitatively. The validation results of the validators got an average validation score of $95.43 \%$ with a very valid category. The results of student responses based on small group trials got an average score of $94.87 \%$ with a very practical category. The results of the large group trial get an average of $88.25 \%$ in the very good category or have a potential effect on student learning outcomes. It can be concluded based on the results of data analysis of TPACK-based learning videos in fraction material for fourth grade elementary school students including learning videos that are valid, practical, and have a potential effect on learning outcomes. Overall, TPACK-based learning videos in fraction material for fourth grade elementary school students have been suitable for use in learning
\end{abstract}

Keywords : Development Of Learning Videos, TPACK, Fractions

\begin{abstract}
ABSTRAK
Penelitian ini bertujuan untuk mengembangkan video pembelajaran berbasis TPACK dalam materi pecahan untuk siswa kelas IV SD yang valid, praktis dan memiliki efek potensial terhadap hasil belajar siswa. Penelitian ini adalah penelitian dan pengembangan menggunakan ADDIE model dengan lima tahapan yakni Analisis, desain, pengembangan, implementasi, dan evaluasi. Penelitian bertempat di SDN 79 Prabumulih. Subjek penelitian yaitu 20 siswa kelas IV SD. Pengumpulan data dilakukan dengan angket validasi ahli media, ahli materi, angket respons siswa, dan tes soal siswa. Data di analisis secara kuantitatif dan kualitatif. Hasil validasi para validator mendapat skor rata-rata validasi $95,43 \%$ dengan kategori sangat valid. Hasil respons siswa berdasarkan uji coba kelompok kecil mendapatkan skor rata-rata 94,87\% dengan kategori sangat praktis. Hasil tes uji coba kelompok besar mendapatkan rata-rata 88,25 \% kategori sangat baik atau memiliki efek potensial terhadap hasil belajar siswa. Dapat disimpulkan berdasarkan hasil analisis data video pembelajaran berbasis TPACK dalam materi pecahan untuk siswa kelas IV SD termasuk kedalam media video pembelajaran yang valid, praktis, dan memiliki efek potensial terhadap hasil belajar. Secara keseluruhan video pembelajaran berbasis TPACK dalam materi pecahan untuk siswa kelas IV SD telah layak digunakan dalam pembelajaran.
\end{abstract}

Kata Kunci : Pengembangan video pembelajaran, TPACK, Pecahan 


\section{PENDAHULUAN}

Perkembangan teknologi yang berlangsung sangat pesat ini berbagai pembaharuan dilakukan dalam meningkatkan kualitas pendidikan memiliki termasuk pula pada saat melakukan aktivitas belajar dalam hal ini tentu merupakan tantangan para pendidik dalam menghadapi tantangan revolusi industri 4.0 untuk meningkatkan mutu pendidikan dan juga menuntut guru dalam menguasai teknologi untuk dintergrasikan dalam proses pembelajaran. Dilndonesia kesiapan menghadapi tantangan pendidikan diera revolusi industri 4.0 adalah segera meningkatkan kemampuan sumberdaya manusia melalui pendidikan dengan melahirkan operator dan analis yang handal dalam bidang pendidikan itu sendiri. (Syamsuar \& Reflianto, 2019). Pendidikan mempunyai fungsi untuk mengarahkan manusi dan mengembangkan manusia itu sendiri sehingga menjadi manusia yang berguna. Diera revolusi industri 4.0 ini guru dituntut untuk berikir kreatif dalam merencanakan pembelajaran, kreativitas guru mutlak dibutuhkan untuk dapat mengubah situasi pembelajaran yang menarik dan efektif sesuai perkembangan zaman. Jika diera revolusi industri 4.0 teknologi mempengharui aktivitas kehidupan, maka guru harus mampu menciptakan gagasan baru merancang kegiatan pembelajaran dengan teknologi digital. (Nahdi \& Cahyaningsih, 2019).

Salah satunya sebagai dengan cara memanfaatkan media dan teknologi dalam mendukung aktivitas pembelajaran-pembelajaran yang sudah usang atau telah lama digunakan sehingga anak-anak semangat dalam menerima pembelajaran karena guru pada abad 21 ini harus memiliki kemampuan memadukan pembelajaran teknologi dan pedagogik atau sering disebut TPACK. TPaCK (Techonological Pedagogikal Conten Knowladge) itu sendiri merupakan sebuah kerangka konseptual gabungan dari pengetahuan teknologi, pedagogi dan konten (materi) yang saling berhubungan Misra dan Koehler (Sukaesih et al., 2017).

Media pembelajaran itu sendiri menurut merupakan salah satu kompenen penting dalam suatu pembelajaran. Dalam bidang Teknologi pendidikan berfungsi untuk menyampaikan materi pelajaran guna dapat dipahami peserta didik. (Pribadi, 2017) Teknologi dalam Media pembelajaran sangatlah beragam dan dapat dimanfaatkan yakni, media cetak, model, grafis, audio, video, multimedia dan koneksi atau jaringan internet yang dapat memfasilitasi serta dapat memperkaya pengetahuan peserta didik namun pememersalahan sekarang masih banyak pendidik yang menggunakan media sederhana saja. Berdasarkan informasi yang diperoleh peneliti yang diperoleh dari guru kelas IV SDN 079 Prabumulih, dalam sistem pembelajarannya sudah lumayan baik namun dalam memberi informasi masih ada guru yang mengajar menggunakan metode 
konvensional atau bisa disebut ceramah dan biasanya juga fokus kebuku saja sehingga membosankan. Terkadang walaupun sudah mempunyai Projector tetapi guru masih kurang memanfaatkan dengan baik, sehingga pada saat proses pembelajaran hanya menggunakan media yang itu-itu saja dan sederhana seperti gambar dalam hal ini tidak akan membangkitkan minat belajar siswa dan cenderung monoton.

Berdasarkan uraian diatas dilihat kurangnya media yang inovatif peneliti membuat pengembangan video pembelajaran berbasis tpack, karena perlu sekali pembelajaran yang menarik dengan media video pembelajaran berbasis TPaCK dengan diberi animasi. Dengan adanya TPaCK maka pendidik diharapkan dapat memanfaatkan teknologi itu sendiri sebagai media dalam memfasilitasi siswa untuk memahami suatu pembelajaran terutama pada matematika. Adanya pengembangan video pembelajaran berbasis $\mathrm{TPaCK}$ diharapkan dapat memotivasi peserta didik dan juga membangkitkan semangat belajar mengenai materi pecahan dan dapat membantu serta memotivasi pendidik dalam menyediakan media pembelajaran yakni video pembelajaran yang sesuai agar mencapai target pecapaian tujuan pembelajaran dengan pendekatan TPaCK (teknological, pedagogical, and content knowladge).

Tujuan pada penelitian pengembangan ini adalah: Untuk menghasilkan suatu video pembelajaran berbasis TPACK dalam materi pecahan untuk siswa kelas IV SD yang valid. Untuk menghasilkan suatu produk video pembelajaran berbasis TPACK dalam materi pecahan untuk siswa kelas IV SD yang praktis. Untuk mengetahui efekpotensial video pembelajaran berbasis TPACK dalam materi pecahan untuk siswa kelas IV SD terhadap hasil belajar.

\section{METODE PENELITIAN}

Penelitian ini merupakan penelitian dan pengeembangan dengan model ADDIE melalui 5 tahapan yakni analisis, design, pengembangan, implementasi dan evaluasi (Sugiyono, 2019). Subyek dalam penelitian ini adalah siswa kelas IV SD. Dalam penelitian ini teknik analisis data untuk menentukan produk yang dihasilkan agar dikatakan layak.

Maka pengumpulan data yang akan di ukur ialah kategori valid dan praktis menggunakan beberapa cara seperti menggunakan walkthrough pada walktrough validasi dilakukan validasi kepada ahli media dan ahli materi dengan dua dosen dan satu guru dengan mengisi lembar validasi untuk menjadi acuan agar produk lebih maksimal, apabila produk yang dibuat mencapai rata-rata $60 \%-80 \%$ maka produk dapat dikatakan valid, setelah video dikatakan valid.

Selanjutnya uji coba kelompok kecil untuk menguji kepraktisan dari video pembelajaran dengan membagikan angket respon siswa kepada 5 orang siswa, apabila produk dikatakan valid dan praktis berdasarkan analisis data 
mecapai $60 \%-79 \%$ produk sudah bisa dikatakan valid dan praktis dan bisa dilanjutkan keuji coba kelompok besar

Pada uji coba kelompok besar dilakukan dengan cara memberikan tes soal mengenai video setelah mereka mengikuti proses pembelajaran menggunakan video untuk mengetahui efek potensial produk yang dibuat terhadap hasil belajar. Siswa dikatakan tuntas apabila minimal hasil belajar klasikal 70\% (Mamin \& Arif, 2019) apabila hasil analisis data dari tes uji coba kelompok besar mencapai kategori 60\%-80\% maka produk bisa dikatakan baik atau memiliki efek potensial.

\section{HASIL PENELITIAN DAN PEMBAHASAN}

Pengembangan yang dilakukan oleh peneliti menghasilkan suatu produk berupa video pembelajaran matematika berbasis TPaCK yang telah divalidasi oleh validator (dua dosen dan satu guru), dan telah diterapkan dalam pembelajaran.

Penelitian dan pengembangan ini mengunakan tahap-tahap pengembangan menurut model pengembangan addie yang dilakukan beberapa tahapan yakni analisis, design, pengembangan, implementasi dan juga (1) Penelitian Informasi awal dilakukan Analisis (2) Melakukan pembuatan perencanaan untuk membuat perencanaan video pengembangan video, pembuatan instrument validasi, (4) Validasi Desain dengan Para Ahli (dua dosen dan satu guru); (5) Revisi produk awal dilakukan dari hasil komentar dan masukan para ahli; (6) Uji Coba Produk skala kecil; (7); Uji coba skala besar; (8) evaluasi.

Penelitian dengan judul pengembangan video pembelajaran berbasis TPaCK dalam materi pecahan untuk siswa kelas IV SD. Penelitian dilaksanakan di SD Negeri 79 Prabumulih dengan subyek penelitian siswa kelas IV.

\section{Tahap Analyis}

Pada tahap awal dilakukan analisis kebutuhan dilakukan dengan untuk mengetahui masalah apa yang ada disekolah agar pengembangan video pembelajaran sesuai dengan kebutuhan siswa. Berdasarkan informasi yang ditemukan juga bahwa selama proses belajar guru hanya menggunakan media yang belum mengikuti perkembangan zaman seperti menggunakan stereofome sehingga kurang menarik.

\section{Tahap Design}

Design dalam membuat video pembelajaran dengan cara pencarian informasi di Internet mengenai jurnal serta penelitian yang relevan tentang pengembangan video pembelajaran berbasis TpaCK dalam materi pecahan untuk siswa kelas IV SD, mencari KI, KD, Indikator, dan Silabus dari Kurikulum 2013, Bukubuku yang digunakan mengenai Video pembelajaran, Mengumpulkan gambar-gambar yang sesuai dengan materi, Aplikasi yang digunakan dalam membuat video pembelajaran 
adalah aplikasi KineMaster, Capcut, Benime, canva dan InShot.

\section{Development (Pengembangan)}

Berdasarkan hasil dari pengembangan dari peneliti yang disebut dengan prototype I . Adapun para validator yang terdiri atas Bapak Moh. Reza Ifnuari, M.Pd Dosen PGSD Universitas PGRI Palembang sebagai ahli media, Bapak Drs. Asrowi, M.Si Dosen Univeritas terbuka sebagai ahli materi matematika. Ibu Afni Yurita S.Pd Guru mata pelajaran matematika kelas IV.

Tabel 1. Analisis angket validasi prototype 1

\begin{tabular}{llll}
\hline No & Validator & \multicolumn{2}{c}{ Rata-Rata (\%) } \\
\hline 1. & $\begin{array}{l}\text { Validator } \\
\text { materi } \\
\text { Validator } \\
\text { materi } \\
\text { Validator }\end{array}$ & Ahli & $73,75 \%$ \\
3. Ahli & $77,5 \%$ \\
& Ahli & $67,95 \%$ \\
\hline Jumlah & & \\
\hline Rata-Rata (\%) & & $\mathbf{2 1 , 9 , 2 \%}$ \\
\hline
\end{tabular}

Setelah didapatkan data validasi nilai belum maksimal dan didapatkan komentar dan saran sebagai acuan revisi agar video pembelajaran menjadi lebih maksimal, kemudian peneliti melakukan revisi dan melakukan validasi kembali. Berikut hasil hasil validasi dengan validator media dan materi :

a. Perbaiki Outro menambahkan outro.
Sebelum direvisi

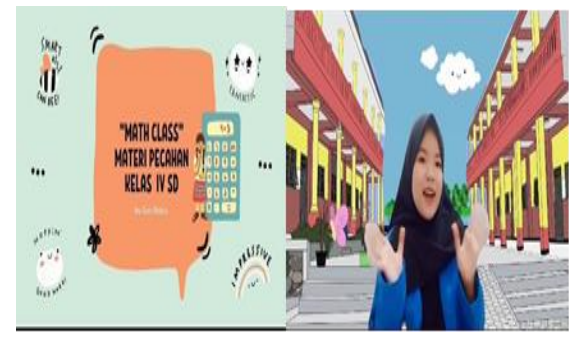

Sesudah direvisi

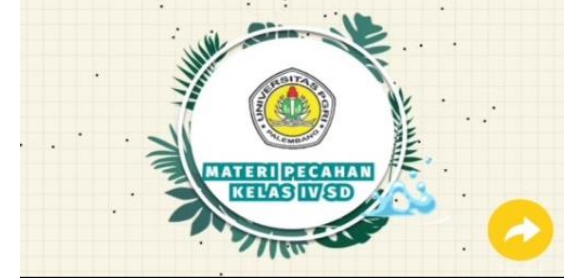

b. Perbaiki gambar sesuai materi

Sebelum direvisi

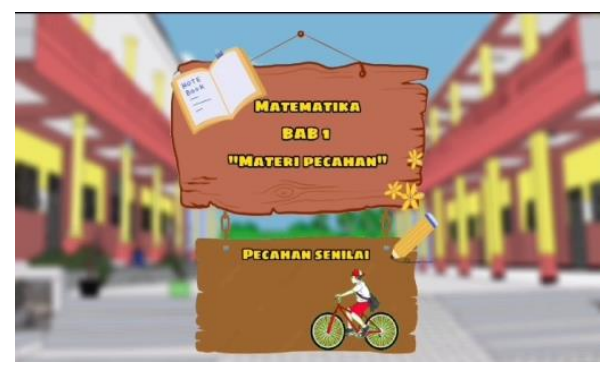

Sesudah direvisi

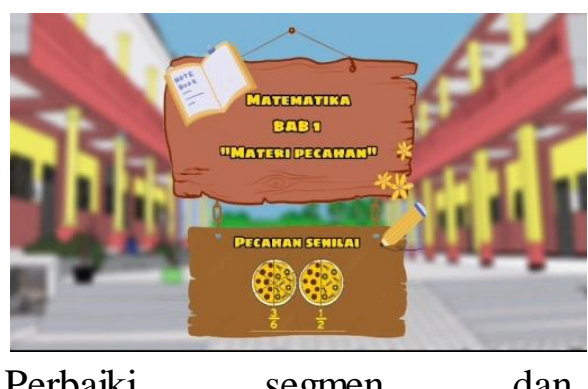

c. Perbaiki segmen dan penambahan toping pada gambar donat pada materi pecahan

Sebelum direvisi

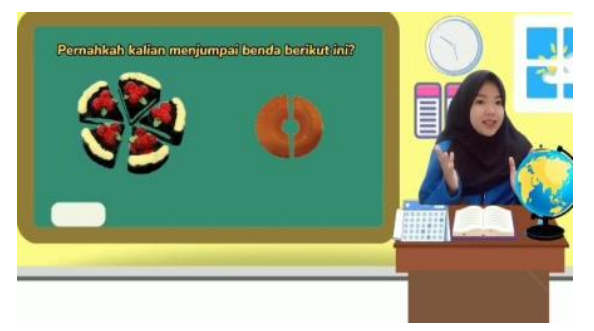


Sesudah direvisi

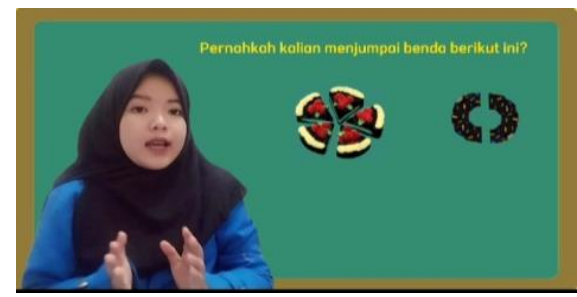

d. Perbaikan menambahkan muncul dibagian segment dianjurkan (pure mengajar )

Sebelum revisi

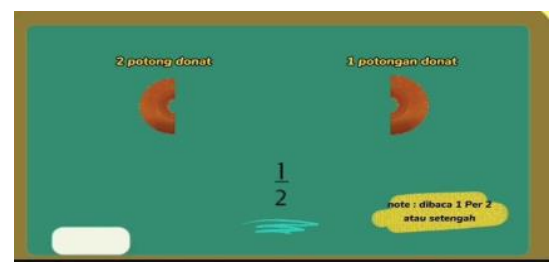

Sesudah direvisi

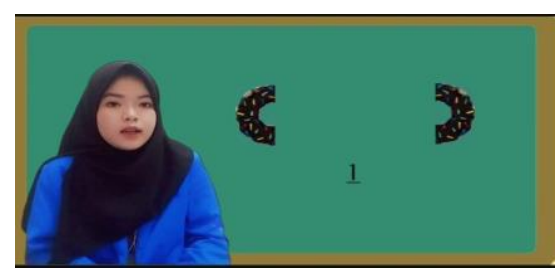

e. Perbaikan Segmen.

Sebelum revisi

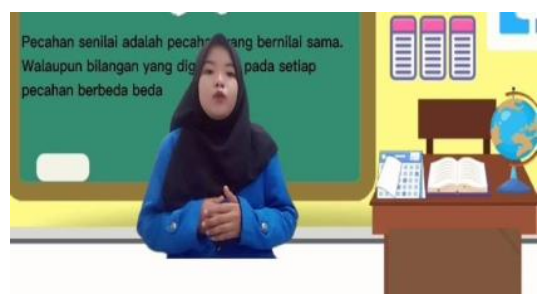

Sesudah revisi

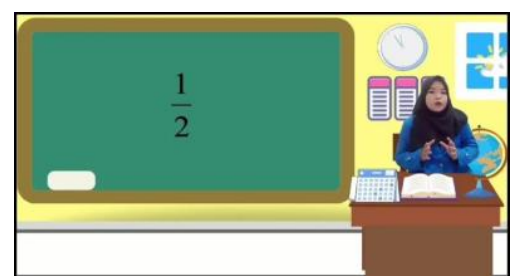

f. Perbaikan penghapusan soal Sebelum revisi
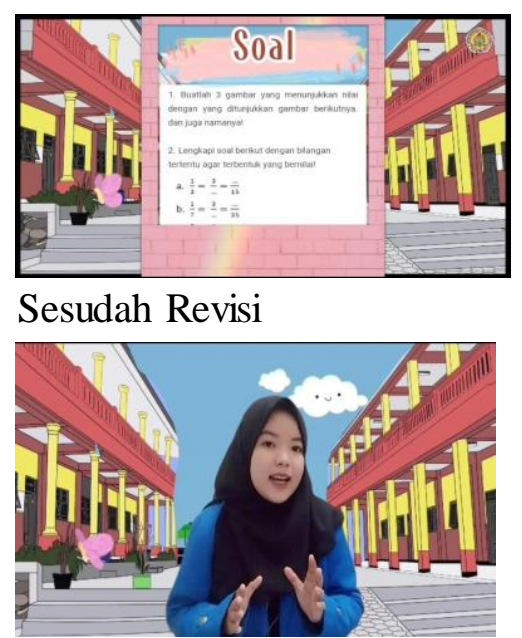

Setelah dilakukan validasi kembali kepada validator dan dapatkan hasil data sebagai berikut ini:

Tabel 2. Analis is Angket Validasi

Prototype 2

\begin{tabular}{llll}
\hline No & Validator & & Rata-Rata (\%) \\
\hline 1. & $\begin{array}{l}\text { Validator } \\
\text { materi } \\
2 .\end{array}$ & Ahli & $95 \%$ \\
& $\begin{array}{l}\text { Validator } \\
\text { materi } \\
\text { Validator } \\
\text { media }\end{array}$ & Ahli & $95 \%$ \\
& Ahli & $96,29 \%$ \\
\hline Jumlah & & $\mathbf{2 8 6 , 2 9 \%}$ \\
\hline Rata-Rata (\%) & $\mathbf{9 5 , 4 3 \%}$ \\
\hline
\end{tabular}

Berdasarkan hasil validasi dari ketiga validator didapatkan nilai ratarata nilai validasi sebesar $95,43 \%$ ketika sudah diperbaiki, sebelum diperbaiki nilai rata-rata validasi sebesar 73,07 \%. Berdasarkan kriteria interpretasi skor yang ada pada bagian teknik analisis data dapat disimpulkan bahwa video yang dibuat dan dikembangkan sudah "sangat valid" berdasarkan kriteria kevalidan sehingga bisa dilanjutkan ke uji coba 
kelompok kecil dan besar atau uji coba kelapangan.

\section{Implimentation}

Uji coba video pembelajaran berbasis TPaCK ini dilakukan pada siswa kelas IV SD Negeri 79 Prabumulih. Terdapat dua tahap uji coba yakni uji coba kelompok kecil dan kelompok besar. Uji coba kelompok kecil dilakukan untuk 5 orang siswa untuk mengisi angket respon siswa. Berikut tabel hasil uji coba kelompok kecil.

\section{Tabel 3. Hasil analisis data ujicoba kelompok kecil}

\begin{tabular}{cccc}
\hline No & $\begin{array}{c}\text { Jumlah } \\
\text { siswa }\end{array}$ & $\begin{array}{c}\text { Rata-rata } \\
(\boldsymbol{\%})\end{array}$ & Keterangan \\
\hline 1 & 5 & 94,87 & $\begin{array}{c}\text { Sangat } \\
\text { valid }\end{array}$ \\
\hline
\end{tabular}

Berdasarkan hasil angket respon siswa yang sangat tinggi pada produk yang dibuat didapatkan nilai rata-rata sebesar 94,87\%. Berdasarkan nilai rata-rata tersebut dilihat dalam tabel kategori presentase skor dapat disimpulkan bahwa video yang telah dibuat dan dikembangkan dikategorikan "sangat praktis" sehingga menunjukan bahwa video ini layak untuk digunakan pada proses pembelajaran setelah dinyatakan praktis maka dilakukan uji coba kelompok besar. Sejalan dengan penelitian (Octavyanti \& Wulandari, 2021) berdasarkan analisis data hasil uji coba kelompok kecil memporoleh presentase 90,62\% (berkualifikasi baik).
Video pembelajran yang sudah memasuk katagori valid dan praktis kemudian diuji coba kelompok besar Data hasil tes berupa soal yang diberikan peneliti kepada para siswa setelah siswa menonton video yang dibuat peneliti, soal yang diberikan adalah 5 soal essay kepada siswa satu kelas. Berikut hasil dari tes hasil belajar siswa disajikan dalam bentuk tabel sebagai berikut :

\section{Tabel 4. Hasil Analisis data uji coba kelompok Besar}

\begin{tabular}{cccc}
\hline No & $\begin{array}{c}\text { Jumlah } \\
\text { siswa }\end{array}$ & $\begin{array}{c}\text { Rata-rata } \\
(\boldsymbol{\%})\end{array}$ & Keterangan \\
\hline 1 & 20 & 88,25 & Sangat baik \\
\hline
\end{tabular}

Berdasarkan data yang didapat dari tes hasil belajar siswa yang telah dilakukan. Berdasarkan tabel diatas didapatkan nilai rata-rata sebesar Mengacu berdasarkan kriteria interpretasi hasil belajar siswa memiliki efek potensial sebesar 88,25 $\%$ dikategorikan sangat baik dalam artian memiliki efek potensial. (Yudianto, 2017) bahwa video pembelajaran merupakan media pembelajaran yang paling akurat dalam menyampaikan pesan dan akan sanagat membantu pemahaman peserta didik dengan adanya video media video peserta didik akan lebih paham dengan materi yang ditayangkan dalam sebuah film.

\section{Pembahasan}

Berdasarkan pada hasil pengembangan video pembelajaran materi pecahan mulai dari prototype I, Prototype II dapat diuraikan hasil 
pengembangan bahan ajar sebagai berikut :

\section{a. Validitas}

Pada tahap validasi dengan memberikan lembar validasi serta angket validasi kepada Ahli media dan ahli materi video pembelajaran perlu dilakukan validasi agar video menjadi lebih maksimal dan valid. Validitas dilakukan oleh beberapa validator yang terdiri atas 1 orang dosen PGSD Universitas PGRI Palembang, 1 orang dosen dari luar yakni dosen Universitas Terbuka dan 1 orang Guru Matematika SD.Pada tahap validasi pertama prototype I mendapat arahan dan komentar sebagai acuan revisi agar video maksimal selanjutnya pada Prototype II dilakukan kembali validasi untuk melihat media apakah telah valid dan sudah layak untuk diuji kelapangan. Setelah mendapatkan nilai dari angket yang diberikan kemudian peneliti menghitung nilai kevalidan dan peneliti mendapatkan nilai rata-rata sebesar 95,43\% setelah divalidasi sesuai dengan kategori presentase maka dapat disimpulkan bahwa video pembelajaran termasuk pada kategori "sangat valid".

Hal ini sejalan dengan penelitian (Octavyanti \& Wulandari, 2021) yang telah dilakukan oleh dengan judul "pengembangan video pembelajaran berbasis pendekatan kontekstual dalam materi matematika kelas IV. Berdasarkan hasil analisis data pada penelitian adalah 91,67 untuk ahli materi (berkualifikasi sangat baik) 93,33\% (berkualifikasi sangat baik) jadi dapat di simpulkan media video pembelajaran layak untuk digunakan dan diuji kelapangan

Berdasarkan hasil pengembangan video pembelajaran materi pecahan mulai dari prototype I, Prototype II dapat diuraikan hasil pengembangan bahan ajar sebagai berikut

\section{b. Praktis}

Berdasarkan hasil validasi setelah prototype I direvisi sehingga didapatlah prototype II yang telah dinyatakan valid setelah melakukan validasi kembali dan dapat di uji cobakan kelapangan . Kemudian peneliti melakukan uji coba kelompok kecil sebanyak 5 siswa. Peneliti meminta siswa untuk mengisi angket respon siswa setelah menyimak video untuk mengukur kepraktisan video yang dibuat. Berdasarkan uji coba kelompok kecil mendapatkan hasil rata rata 94,87 \% tidak perlu melakukan revisi terhadap prototype II karena termasuk "kategori sangat praktis".

Sejalan dengan penelitian (Rebowo, 2014) dengan judul 'Pengembangan media video berbasis Materi Pecahan Pada Siswa Kelas IV Sekolah Dasar. Setelah dianalisis siswa hasil enelitian ini hasil pemberian angket mendapatkan ratarata skor $94 \%$ yang berada dalam kategori(sangat baik) sehingga dapat diuji cobakan tahap lanjut.

Berdasarkan hasil pada pengembangan video pembelajaran materi pecahan mulai dari prototype I, Prototype II dapat diuraikan hasil 
pengembangan bahan ajar sebagai berikut:

\section{a. Efek Potensial}

Tahap selanjutnya untuk mengetahui media yang digunakan memiliki efek potensial terhadap hasil belajar peneliti membagikan soal Essay mengenai materi pecahan kepada kelompok besar dengan jumlah siswa 20 orang setelah siswa menyimak video pembelajaran. Berdasarkan data yang diperoleh hasil belajar rata-rata yang di peroleh oleh siswa yaitu sebesar 88,25\%, dimana berdasarkan kategori rata-rata presentase (Sangat baik). Dapat disimpulkan bahwa video pembelajaran yang dikembangkan sangat menarik dan membuat siswa antusias dalam belajar sehingga mudah memahami materi tersebut.

Sejalan dengan penelitian (WORO, 2021) dengan judul pengembangan video pembelajaran dalam pemecahan masalah matematika materi pecahan peserta didik kelas. Hasil penelitian menunjukkan bahwa rata-rata skor uji coba kelompok besar adalah 89,74 yang memenuhi standar penjelas yaitu "sangat baik". Maka video pembelajaran layak dan efektif untuk hasil belajar siswa

\section{b. Evaluation}

$$
\text { Pada tahap ini dilakukan }
$$

mulai dari tahapan design sampai kelapangan atau implementasi yang bertujuan untuk mengetahui kevalidan, kepraktisan serta efek potensial video yang dibuat dan dikembangkan terhadap hasil belajar.
Pada tahap evaluasi juga untuk mengetahui kekurangan dan kelebihan dari bahan ajar berdasarkan komentar/saran dari para ahli dan pakar sebagai validator.

\section{SIMPULAN}

Berdasarkan penelitian yang telah dilaksanakan oleh peneliti mengenai "Pengembangan Video pembelajaran berbasis $\mathrm{TPaCK}$ dalam Materi pecahan untuk siswa Kelas IV" didapatkan kesimpulan sebagai berikut: Video pembelajaran matematika materi pecahan dengan menggunakan model penelitian model ADDIE dinyatakan telah "Sangat valid" dengan rata-rata validasi sebesar 95,43\%. Video pembelajaran matematika materi pecahan dengan menggunakan model ADDIE dinyatakan sangat praktis berdasarkan hasil uji coba kelompok kecil didapat rata-rata 94,87 \% Sehingga produk video pembelajaran tersebut "Sangat Praktis"jadi produk pengembangan dinyatakan praktis untuk digunakan. Video pembelajaran Matematika materi pecahan menggunakan model penelitian model ADDIE memiliki efek potensial terhadap hasil belajar. Berdasarkan hasil uji coba kelompok besar mendapatkan rata-rata masuk kategori sangat baik atau memiliki efek potensial sebesar $88,25 \%$ terhadap hasil belajar.

Berdasarkan pernyataan diatas maka dapat disimpulkan video pembelajaran berbasis TPACK dalam materi pecahan untuk siswa kelas IV SD telah valid, praktis, dan memiliki efek potensial terhadap hasil belajar telah layak digunakan pada pembelajaran. 


\section{DAFTAR RUJUKAN}

Al Farizi, Z., Sulisworo, D., Hasan, M. H., \& Rusdin, M. E. 2019. Pengembangan Media Animasi untuk Mendukung Pembelajaran Berbasis TPACK dengan POWTOON pada Materi Torsi SMA Kelas XI. Jurnal Penelitian Pembelajaran Fisika, 10 (2), 108113.

Ekayani, P. 2017. Pentingnya penggunaan media pembelajaran untuk meningkatkan prestasi belajar siswa. Jurnal Fakultas Ilmu Pendidikan Universitas Pendidikan Ganesha Singaraja, 2(1), 1-11.

Huda M. 2017. Model- Model Pengajaran dan Pembelajaran. Yogyakarta : Pustaka Belajar

Mamin, R., \& Arif, R. N. H. 2019. Efektivitas media pembelajaran avideo tutorial terhadap hasil belajar mahasiswa pada Matakuliah IPA Sekolah. Seminar Nasional LP2M UNM.

Meryansumayeka, M., Yusuf, M., \& Suganda, V. A. 2018. Pengembangan video pembelajaran berbasis PMRI untuk mendukung mental calculation siswa dalam permasalahan aritmatika sosial. Jurnal Elemen, 4(2), 119-130.

Nahdi, D. S., \& Cahyaningsih, U. 2019. Keterampilan Guru SD Dalam Menghadapi Era Revolusi Industri 4.0. Social, Humanities, and Educational Studies (SHEs): Conference Series, 2(1), 57-63.

Octavyanti, N. P. L., \& Wulandari, I. G. A. A. 2021. Pengembangan
Video Pembelajaran Berbasis Pendekatan Kontekstual Pada Mata Pelajaran Matematika Kelas IV SD. Jurnal Edutech Undiksha, 9(1).

Sintawati, M., \& Indriani, F. 2019. Pentingnya Technological Pedagogical Content Knowledge (TPACK) Guru di Era Revolusi Industri 4.0. Prosiding Seminar Nasional Pagelaran Pendidikan Dasar Nasional (PPDN) 2019, 1(1), 417-422.

Sharli, Y, A., Nila, K., \& Misdalina 2021. Develompent of social Aritmetic Teaching Materia; Using IT based PMRI Approach For SMP Students. Jurnal Pendidikan Matematika, 15(02) 191-202

Sugiyono. 2019. Metode Penelitian pendidikan. Bandung: Penerbit Alfabeta

Syamsuar, S., \& Reflianto, R. 2019. Pendidikan dan tantangan pembelajaran berbasis teknologi informasi di era revolusi industri 4.0. E-Tech: Jurnal Ilmiah Teknologi Pendidikan, 6(2).

Wisada, P. D., \& Sudarma, I. K. 2019. Pengembangan media video pembelajaran berorientasi pendidikan karakter. Journal of Education Technology, 3(3), 140-146.

Yuanta, F. 2020. Pengembangan Media Video Pembelajaran Ilmu Pengetahuan Sosial pada Siswa Sekolah Dasar. Trapsila: Jurnal Pendidikan Dasar, 1(02), 91-100. 